\title{
The Social and Economic Impacts of Ruaha National Park Expansion
}

\author{
Agnes Sirima \\ Department of Wildlife Management, Sokoine University of Agriculture, Morogoro, Tanzania \\ Email:agnes@suanet.ac.tz
}

Received 5 May 2016; accepted 30 May 2016; published 2 June 2016

Copyright (c) 2016 by author and Scientific Research Publishing Inc.

This work is licensed under the Creative Commons Attribution International License (CC BY). http://creativecommons.org/licenses/by/4.0/

(c) (i) Open Access

\begin{abstract}
Displacement of people to allow expansion of protected areas involves removing people from their ancestral land or excluding people from undertaking livelihood activities in their usual areas. The approach perpetuates the human-nature dichotomy, where protected areas are regarded as pristine lands that need to be separated from human activities. Beyond material loss, displaced communities suffer loss of symbolic representation and identity that is attached to the place. The aim of this paper was to assess impacts of Ruaha National Park expansions to the adjoining communities. Five villages were surveyed: Ikoga Mpya, Igomelo, Nyeregete, Mahango and Luhango. All participants were victims of the eviction to expand the park borders. Based on the conceptual analysis, major themes generated were: loss of access to livelihood resources, change in resource ownership, conservation costs, resource use conflict, place identity, and the role of power. Similar to previous studies, results show that local communities suffered both symbolic and material loss as a result of park expansion. Furthermore, it has shown that conflicts related to land use changes have roots within (pastoralist vs. farmers; Sangu vs. Sukuma) as well as from the outside. Hence, to better understand resource access and ownership, a deeper understanding of community characteristics/composition and their local interaction is important. Further, park expansion needs to take into consideration human livelihood need.
\end{abstract}

\section{Keywords}

Conservation, Displacement, Ruaha National Park, Protected Area

\section{Introduction}

Conservation organizations at national, regional and international level are pushing for expansion of protected areas to serve as the last remaining ecosystem on earth [1]. A notable expansion of protected areas has been recorded between 1911 and 2011 where the number of protected areas increased from 153 to over 157 thousands 
covering about $12.7 \%$ of the world terrestrial land and $1.6 \%$ of the marine areas [2]. Scientists, however, are arguing for more protected area coverage to ensure that the world remaining natural wealth is given utmost protection [3]. With that proposition, more human-restricted reserves and more conservation induced displacement are expected to increase. More often, conservation induced displacement costs are borne by people living adjacent to these protected areas. The cost may associate with loss of forest and land resources potential for livelihood activities as well as social ties developed over the course of living in or around the area.

The conversional approach (the Yellowstone model) to conservation that demands "no human settlement" within the park boundaries has resulted in displacement of human population. The approach perpetuates the human-nature dichotomy, where protected areas are regarded as pristine lands that need to be separated from human activities. The neglect of human role in nature conservation has led to the ever ending conflicts between rural communities and authorities that are responsible for managing protected sites [4]-[9], resulting into growing lack of confidence, trust, and even hatred between protected area managers and surrounding communities.

Displacement for conservation comprises of removing people from ancestral land [10], or excluding people from undertaking livelihood activities in their usual areas (see [11]). Beyond material loss, displaced communities suffer loss of symbolic representation and identity that is attached to the place [12]. Several authors contributed to the conservation displacement debate looking at rationale of expansion and impacts of protected areas expansion/establishment to rural communities [8] [10] [13]-[17]. Although conservation agenda has changed to reflect on the social inclusion of those living adjacent to it [18] [19], the change has been, to a large extent, paper based.

\section{Conservation and Displacement in Tanzania}

Land loss for conservation has been a recurring theme in East Africa over the last century [20]. In Tanzania it has been a prominent feature especially in the rural areas [20]. Historically, displacement for conservation is linked to colonialism in the name of nature conservation strategies, by creating national parks and game reserves mostly adopting conservation models from western countries prior to assessing its effectiveness and impacts on the receiving end. In most occasions, wildlife habitat destruction and increased agriculture activities were the two main motives for systematic eviction [21]. To Deihl, it seems "ironic... that one of the first step in establishing a national park is to rid the region of its original caretakers” ([22], p. 37). Protected areas in Tanzania have been created to serve dual mandate; to conserve wildlife resources as well as providing space for leisure and recreation [23]. Surprisingly as rural communities are excluded, tourists are granted access to these areas, investors are allowed to build lodges and other tourist facilities to enhance enjoyment of visitors.

Wildlife conservation in Tanzania dates back during the pre-colonial era where wildlife resources were managed by communities. The management system changed during the German colonial era where rules governing wildlife consumption were enacted. Some of these early regulations put forward (such as hunting e.g. introduction of license and fees, hunting with firearms, etc.) limited the participation of traditional societies in wildlife hunting activities [24]. The alienation denoted initial steps of human displacement from protected areas by limiting rural user traditional rights. Rules prohibiting dry pasture movements were also put in place, confining early pastoral societies to a small area [25]. Generally, all early rules and regulations that govern wildlife management made it increasingly difficult for rural communities to access resources found in these areas.

Similar events were observed in 1954 when human activities within Serengeti Game Reserve were restricted, followed by upgrading of the reserve to a full-fledged national park in 1959 [25]. In 1974, Maasai communities, previously relocated from Serengeti National Park were, again, relocated from the two crater areas within Ngorongoro Conservation Area [26], the place they resettled after being displaced from Serengeti NP in 1954 (Table 1).

Conservation activities in Tanzania have witnessed a change in management regime with the aim of devolving management authorities of resource management to the local communities. Despite the efforts, management approaches are still top-down and communities to a large extent are still at the margin. Further, programs such as Reducing Emission s from Deforestation and Forest Degradation (REDD), agriculture intensification projects (cf. Southern Agricultural Growth Corridor of Tanzania-SAGCOT), large scale biofuel plantations, and other programs of similar nature exacerbate the problem by annexing agricultural land from the rural communities (see [27]).

The current research is building against the conservation displacement arguments raised, by addressing on the social and economic impacts of Ruaha National Park expansion. The aim is not to quantify the impacts but 
Table 1. Selected series of human displacement for conservation in Tanzania.

\begin{tabular}{|c|c|}
\hline Year & Event \\
\hline Early 1939 to 1945 & $\begin{array}{l}\text { Maasai who used to live in Serengeti are forcibly moved to NCA paving way for the upgrading of the Serengeti } \\
\text { National Park }\end{array}$ \\
\hline 1960 & Establishment of Maasai Mara National Park in Kenya to join Serengeti, blocking the movements of Maasai \\
\hline 1974 & People were removed from two craters inside the Ngorongoro Conservation Area \\
\hline 1975 & Cultivation inside NCA was prohibited \\
\hline 1976 & Maasai were prohibited to enter Oldupai George \\
\hline 1980 & Firewood collection by Maasai were prohibited \\
\hline 1985 & $\begin{array}{l}\text { Establishment of structural adjustment policy which prohibited pastoralists' use of land for grazing and given to } \\
\text { commercial agricultural investment, mining companies and wildlife conservation expansion in Simanjiro area }\end{array}$ \\
\hline 1987 & Anti-cultivation practices around NCA were operationalized \\
\hline 1988 & Eviction of pastoralist from Mkomazi Game Reserve \\
\hline 1994 & Eviction of people from Saadani National Park \\
\hline 2000 & Forceful eviction of peasant farmers from Ikorongo/Grumet Game Reserve \\
\hline 2006 & $\begin{array}{l}\text { Forceful eviction of pastoralists and relocation of rural communities from Usangu plains, followed by Ruaha } \\
\text { National Park expansion }\end{array}$ \\
\hline
\end{tabular}

rather to learn from the displaced communities about their perceived social and economic impacts after being relocated from areas adjoining Ruaha National Park. Two key questions guided this study: 1) What kind of natural resources have rural communities had access to and how has the access changed after the park expansion? 2) What are the changes in resource ownership associated with land use changes around the park?

\section{Methodology}

\subsection{Study Site Description}

Ruaha National Park “Dream of Africa” was the second largest national park after Serengeti, originally covering an area of 10,300 square kilometres. Ruaha derived its name from the Great Ruaha River which flows along its stream border creating spectacular gorges [28]. Located in central Tanzania, $128 \mathrm{~km}$ (80 miles) west of Iringa town, Ruaha National Park, after expansion, now covers an area of 20,226 square kilometres. The major reason for the parks expansion was to secure the Usangu basin as the main catchment areas for Mtera and Kidatu power houses for hydroelectric system in the country [29]. The annexation of Usangu basin has doubled the size of Ruaha National Park and transformed it to be the largest National Park in Tanzania, the second largest wildlife protection area in Africa, after Kafue National Park in Zambia [29]. During the expansion process seven villages and two hamlets included within the park boundaries, and pastoralist's communities formally residing in those areas were relocated to Lindi and Pwani regions. Others remained and resettled in nearby villages around the park.

\subsection{Data Collection}

Semi-structured interviews and field observation were the main techniques used to collect data. The target population was the communities' formerly residing in park expanded area. In addition, other communities that utilized the annexed land for livelihood activities but not residing in the area were included in the study. Semi structured interviews was chosen as the data collection method because it provide a better understanding of opinions, values, attitudes, feeling and the issues that people have in common [30]. All the interviews were conducted in Swahili language and were audio recorded. Each interview lasted for about 45 minutes to 1 hour and centred on the livelihood change, and resource access and ownership before and after park expansion. Seventy eight, one-to-one interviews were conducted in five villages; Ikoga Mpya, Igomelo, Mahango, Nyeregete and Luhango. Data saturation was used to determine the total number of interviews conducted. Detailed field notes were taken during each field visits. Secondary data were used to obtain information about general eco- 
nomic activities in the district and other population characteristics. All recorded interviews and focus group discussion were transcribed, translated to English and prepared for coding. Interpretive analysis was used to look for meaning and interpretation of information gathered. Texts from the field data were then broken down into more meaningful pieces of information, and codes then were assigned to represent recurring themes in the findings. Reflexive analysis was also used in order to ensure that data retain its original context. Based on the conceptual analysis, major theme generated were: loss of access to livelihood resources, change in resource ownership, conservation costs, resource use conflict, place identity, and the role of power.

\section{Results}

\subsection{Participants' Profile}

Semi structured interviews were conducted to both men and women from five purposefully selected villages; Igomelo (9 interviews), Ikoga Mpya (21 interviews), Luhango (16 interviews), Mahango (10 interviews), and Nyeregete (20 interviews). Interviews were mainly conducted to individuals evicted from areas that are currently annexed to Ruaha National Park. The aim was to gather their opinion on the process and the impact of displacement. Participants were drawn from diverse ethnic background, comprising almost all the subgroups available in the area. Participants' age range between 20 - 80 years, with most of the participants in their early 30's to late 50's. The main socio-economic activity for the respondents was farming $(\mathrm{n}=63)$, pastoralists $(\mathrm{n}=3)$, both farming and pastoralists $(n=5)$ and other economic activity $(n=12)$. Female constitutes about $33 \%(n=31)$ while male were about $66.67 \%(n=62)$ of study participants. The fewer number of the pastoralists in the area is attributed to displacement, which relocated most of local communities to Lindi and Pwani regions. Furthermore, those who remained behind have changed economic activity due to the decrease in grazing grounds and loss of livestock during the eviction process.

\subsection{The Eviction Process}

The process to evict pastoralists and relocate some of the villages was explained as violent, harsh and top down. The operation was held in 2006. Majority of communities complained on the harsh conditions and unfair treatment received from officers handling the process. Furthermore, a significant portion of communities claim to unaware of the process, and were surprised when they were told to vacate the area. However, others claimed to know the relocation plan were prepared for the process. Those who knew, claim that the debate for park expansion started with education to reduce the number of cattle in the area followed the possibility of eviction for park expansion. These events were conducted in phases, and they claim to be involved throughout and they had chance to ask questions.

Further, communities complained on the promises made to them before the eviction process. Majority felt that the government did not fulfil the promise and some blamed Tanzania National Parks (TANAPA) for not fulfilling what they have agreed before the eviction process. Furthermore, communities also complained about the unsuitable living conditions in the areas they have relocated to.

In that place there was enough grazing land, and we had farms. They told us to leave the place for wildife reserve and they told us we were going to be compensated for everything like trees, houses, and we agreed... they promised to build school, give us places to cultivate and everything that we had before... including everything else that we owned (Participant \#1).

Some communities complained that the government did not make a follow up to see how they fared after relocation nor did they provide full infrastructural support to the places that they were promised would be provided.

They promised to provide full infrastructural services where we are going including schools, water, roads, and hospital etc. ... we only found four classrooms, toilets, and a dispensary. No cattle dips, no teachers or facilities at schools, no water, no health workers... until now there are so many pregnant children in the area, they are not going to schools, these are the things which continue to affect us. You have seen the school, are there students? Dispensary, are there doctors? We do not want to talk things in vain you have to see by yourself... Now we have started our own clinic to care for our children, we will take you there (Participant \#15). 
The feeling of betrayal and abandonment might be the reason why many rural communities felt that they were not involved or were not part of the relocation decision making. Although the decision to evict them had already been made, the question for involving communities hinged on how the process was going to be implemented and how they were going to be compensated for loss of land livelihood sources. What had been agreed previously and what actually transpired during and after the eviction portrayed a different picture. Statements below showed that there was a breach of promises/agreements between communities and the government hence the feeling of betrayal and resentment among many rural communities towards the government.

... the difference came during the implementation of the programme. During the process we agreed on many things but it was the opposite when they came to implement, everything was different, they cheated on us... When they came, they talked to us in a friendly way but during the implementation it was different (Participant \#20).

People were involved, but when you tell someone to leave the place and go to another area while you have not prepared the place to live, where do you think that person would stay? (Participant \#4)

When asked to respond on some of the issues, village leaders commented that Mulungu Village was one of the places set aside for communities to stay after eviction. Although Mulungu had the necessary infrastructural facilities (one school, one water well and a dispensary) most of communities did not choose to go there.

Mulungu was a place set aside for all the people to settle. Infrastructural facilities like school, rural roads, and water were already put in place. About 906 plots were also set aside as residential plots for those who will choose to stay. People did not choose to go; they stayed at nearby villages except Ikoga which choose to leave as a village. It is an individual decision to choose where to stay and government cannot force people (Participant \#35).

When communities asked about the decision not to resettle at Mulungu, majority said it was very isolated and far from other areas. Furthermore, they commented that infrastructure facilities at Mulungu are not enough for all the evictees. Since many communities chose to stay in nearby areas rather than Mulungu, social amenities in the villages they chose to resettle have been overstretched due to overcrowding.

An interesting move was noted with Ikoga village that decided to move together as a village in another area and branded their name as "Ikoga Mpya" literally meaning New Ikoga. For Ikoga Mpya, TANAPA, through their outreach program, have managed to build a new school, health facility and a borehole and other amenities to support communities. Communities contributed to the development through provision of labour. They have also built toilets so that a recently constructed dispensary could be used.

Although a school was built by TANAPA, classrooms were not sufficient to cater for the resident population. Only four classes were built by the program while normal primary school infrastructure in Tanzania requires at least seven classes. Some rural communities decided to take their children to schools in nearby villages whereas other children dropped out of schools. Furthermore, the communities have decided to put their own initiatives in health facilities by starting a "local clinic" so that their children's could get service needed, otherwise they have to walk several kilometres to get to the nearby health centre. During this study (three years after the eviction) social services have not been provided to the communities. Most of the communities felt abandoned by the government, which had contributed to underdevelopment and increased poverty.

Although most of the community members were compensated, none seem to be satisfied with the compensation received. This may be due to the fact that the evaluation process was conducted a year before the actual payments were made. Communities complained that they were not consulted during the evaluation process hence majority got less than what they actually deserved or bargained for. The evaluators arrived, filled-in forms and left the place without talking or negotiation with the land owners.

The eviction was not fair, the compensation was not enough. I cannot talk much but when you are relocating people you are supposed to pay them what they deserve (Participant \#1).

Some infrastructural facilities were provided to some areas where communities relocated regarded the amenities to be part of their compensation. For example in Ikoga Mpya village where TANAPA built four classrooms, toilets, one water well and a dispensary, some villagers thought they were part of their compensation while others viewed them to be a debt that TANAPA owed since the government promised those facilities while they were still living in their previous village, the area which is now inside the national park. 
TANAPA built this school through Community Conservation Services (CCS) although there are two different explanations; some said it is through CCS some said it is part of our compensation. We do not know what the truth (Participant \#2).

\subsection{Resource Access and Ownership}

Main park expansion impact included increased livelihood risk and lost opportunities. Communities claimed to have lost grazing land, fishing grounds, and other livelihood resources. When asked to describe livelihood resource availability before and after displacement, majority of the communities claimed to be on the disadvantage side with no access to fishing ponds, grazing land, firewood, medicines, and thatching materials. Communities' further mentioned the loss of ritual places as well as social services like schools, water and health centres. The most frequent occurring response was the loss of grazing areas, fishing ponds and livelihood sources. This is because to many people, Ihefu wetland used to offer dry season grazing ground to majority of pastoralists in the area. Ihefu was also considered to be a good breeding ground for cattle. Apart from providing good pasture land, Ihefu was also a source of thatching grass for majority of communities. Local people were also getting firewood, medicine, fish and some other useful materials from the area, and many of these resources served as a subsistence resource as well as sources of income. Following park expansion most of the communities lost access to these areas, and were frequently forced to purchase some of the livelihood resources that they used to get for free.

When we were at Ikoga we had our farms, we were fishing... but after reaching here nothing is going on (Participant \#40).

Although locals were compensated for the land loss, majority still complained of lack of land to buy or the land being too expensive beyond the compensation they received. Similar complaints were noted with Maasai communities in northern Tanzania (cf. [31]).

Usangu wetland is one of the valuable freshwater sources in the country. Apart from offering ecosystem services, fishing was one of the common activities carried out in the area. Fishing in Usangu has been a tradition, a source of food and income to communities [32]. Fishing activities started to diminish when Usangu Game Reserve was first established in 1998. After expanding the national park boundaries, all fishing activities stopped. This is because all potential fishing points are now inside the national park boundaries. Former fishermen complained that banning of fishing activities in the area have changed their lives as they used fish for food but also sell for cash income. Fish as a resource has become expensive to the extent most of the community members cannot afford. Those who depended entirely on fishing from major rivers have shifted to agriculture. As one of the interviewee commented, "there is nothing going on there now, all the fishermen are now engaged themselves in agriculture".

Similar to the loss of access to resources before park expansion, communities in Usangu also lost ownership to some or all of the valuable resources previously owned such as land, houses and business. Land use changes within the last ten years have made people to lose the land ownership most of which was acquired traditionally and was used for livelihood activities. In terms of business, majority, especially women used to operate smallscale businesses such as food vending and petty cash trading, which now they cannot do in the areas they have resettled.

I had good life before eviction; I used to do small business like making doughnuts and rural brews. But as you can see me now, there is nothing going on, I just stay at home" (Participant \#70).

Another community member commented that farming has become an expensive activity; "We never used to have problems on where to farm, but now we have to rent plots. If you plough using hand hoe it costs you about TSh. 21,000/ = per season (approx. \$10), while using ox-plough costs about Tsh. 31,500/ = per season (approx. $\$ 15)$ ". Majority of communities used to have farm plots and place to raise cattle like goats, pigs, chicken, and sheep. Given the small nature of the plots set aside for relocation, most of the communities were forced to sell what they have to accommodate the change.

\subsection{Identity Attached to a Place}

Places hold special meanings to people that have developed a sense of attachment and symbolic identity to the 
area [33]. The Sangu tribe, for example, hold the same for their ancestral land. To them, Ihefu was believed to be a source of rain, and hence only permitted activities were allowed in the area. They had a ritual place known as NG'riama, assumed its name from the clan which was in control of the place. NG'riama was used for ritual and traditional ceremonies, the activity which was practised for centuries by clan leaders. Yearly, clan leaders and community elders would visit the places for these activities praying for the rain to come. Historically part of what now is inside the park boundaries used to be a sacred place where tribe leaders used to conduct rituals. Elders also had the mandate to control other activities such as hunting and fishing that are going on in the area. Initially each year leaders would join together for these ritual practices. They used to meet few days before the actual practice for prayers, which helped them ensure that everyone who attended was spiritually cleansed. Also there was quarantine for a certain times of the year when no one was allowed to visit or do any activity in the area in preparation for the ritual ceremony. Using their local knowledge and having shared similar belief, it was easier for people to regulate use of natural resources. Most of this power however, started to diminish when other tribes settled in the area. Currently most of these activities need permission from the national park authority which communities claim to be taking long time and often permits are granted when the date for certain events has passed.

Similar to the death of the ritual practice, communities also complain to have lost connection with their forefathers whose graveyards are still on the evicted places. They cannot freely visit the places without permits. Majority lost hope of keeping the tradition as it is muddled with politics and state policies and fear that in the future, the history, culture and tradition of the place will be irretrievably forgotten. The feeling of disconnect from annexation of ancestral land is felt highly among the older generations, given the history, memories and attachment most had developed to the place as opposed to younger generations.

\subsection{Resource Use Conflict}

Although the study did not intend to focus on conflicts over natural resources in Usangu plains, it only used the history of resource use conflicts to analyse its contribution in shaping the Ruaha National Park expansion debate. The intensity and dimensions of conflicts over access to natural resources vary from place to place [34]. People all over the world compete over natural resources to enhance their livelihood. In Usangu plains, there has been an on-going resource use conflict among its users (see [15] [34]-[36]). Most of these local conflicts in the area can be grouped into three; using the ethnic lenses (Sukuma vs. Maasai), economic activities (farmers vs. pastoralists), and authority to resources (subsistence vs. commercial).

Divisions that existed within the community with regard to ethnicity and economic activities shaped the way land use changes and negotiations have been handled in the area. There has been a long history of conflicts among the Sukuma, Maasai and the indigenous Sangu over resource use [15] [36]. Sangu are more engaged in farming activities while the Sukuma and Maasai are livestock keepers. The Sangu used to regard immigrant livestock keepers especially the Sukuma as reckless, and source of environmental degradation due to their nomadic style of cattle keeping and "slash and burn" agricultural practices.

When Sukuma came to Usangu they did not observe our traditional land use and they used to take their cattle even in the places that we, as wenyeji have never gone (Participant \#22).

Conflict between Sukuma and the indigenous Sangu has been documented earlier (see [34]). The displacement of pastoralists has been a relief to the Sangu because their crops will no longer be trampled by cattle. This observation was offered by [37] as critical in understanding environmental problems embedded in different social structures because if the conservation efforts affect one group more than the other, the outcome could be different on each group.

There have been also conflicts between the rural communities and the state over the use of resources in the area. The conflict revolves around subsistence vs. commercial resource use. The conflicts started with gazettement of Usangu Game Reserve where pastoralists were deprived of grazing land as well as access to subsistence hunting. This confrontation between rural communities and the government has led to a number of administrative issues in Usangu plains (see [15] [34] and consequently government decision to expand the park.

\subsection{Role of Power}

Within Usangu basin, two main actors were identified, rural communities and Government (both central and lo- 
cal). It is expedient to conclude that communities were not actively involved on discussing and ultimately deciding their fate prior to park expansion. Supporting earlier displacement findings, Ruaha National Park expansion creates unequal power relations, unequal cost-benefit sharing among its actors, as well as marginalization of rural communities from livelihood resources [14] [20]. Being in the grassroots positions, communities were overpowered by other actors, notably the government, conservation agencies and donors who had stronger influence on the policies and regulations. There is a long history of land use change and shift of management systems in Usangu area due to the conflicting interest among diverse actors (see [8] [15]). Throughout the shift, communities were at disadvantaged position; hence their resistance to park expansion was logical. Ruaha National Park expansion emphasized how power is manifested among different actors (e.g. state vs. rural communities) in natural resource management.

\subsection{The Cost of Conservation}

Agriculture is one of the leading economic sectors in Tanzania and Mbarali District is one of the unique districts with large estate farms owned by individuals or cooperative societies. In Mbarali District for example, more than $83 \%$ of its population depend on agriculture [38]. Following park expansion, the district area size has been reduced by $9000 \mathrm{~km}^{2}$ from its original size of $16,000 \mathrm{~km}^{2}$. Meaning, the land potential for agricultural activities has been reduced. Communities living around the area have benefited from agricultural activities hence taking out $9000 \mathrm{~km}^{2}$ from the total district land size restrain potential areas for agricultural and other livelihood activities.

Herders who sent their cattle to Lindi and Pwani regions claimed to have lost most of cattle due to inadequate pasture areas and diseases. This was explained by community members who decided to return back to villages near RNP after failing to survive with their cattle in Lindi and Pwani Regions. The eviction forced them to change their livelihood strategies to cope with the situation. Majority of pastoralists shifted to subsistence agriculture with the hope of buying new cattle with income from selling crops.

Previously I was famous pastoralist, I had 700 cattle's, and then they told us to leave Ihefu. They came directly to me and told me to vacate the place within 10 days; it was not possible for me to leave within that time as I had to look for transport and money to take my cows. And it was not less than 1,000,000 Tsh. (in approx. €550) to hire a car to Lindi. So I decided to take my cows to National Ranches Corporation (NARCO) for grazing. They followed and capture all my cows from NARCO and drag them to Mambi Village. They beat me, while I did not even steal those cows, they were mine. They confiscated my cows for seven days. When I went to get my cows I only found 300 cows, the rest were stolen. I had to sell 100 cows to get money to transfer the rest to Lindi, and then I remained with 200 cows. In Lindi my cows started to die due to diseases and change of the environment, I had to exchange my cows with the specie that survive in the area. I am now left with 80 cows only in Lindi, from 700 I once had. This is our government which says that is fighting for the poor. I am asking the government to hear my voice and give me agricultural inputs so that I may also engage myself in agricultural activities, the cows I have now are not enough! (Participant \#5).

Overall, local communities are on the losing side. In areas where communities were relocated, infrastructural facilities were also lost including health facilities, water infrastructure and schools. Generally, over 400 families were evicted, about 320,000 livestock were lost in the operation and pastoralists were forced to pay fines for "damaging the environment.” Most of the fines range from 10,000 TSH (approx. US \$5) per cow/bull and 5000 TSH (Approx. US \$2.5) per sheep or goat. Given that most of the pastoralists were not ready to pay such amount of money, majority exchanged the fine with cattle. Many families had to transport their livestock by designated trucks at a price of Tsh. 3 million (US \$3000) per truck load. A maximum of 20 herds of livestock per household were allowed to remain in the area. The fines and relocation cost was felt highly by majority of pastoralist since they were not prepared for the move financially and mentally.

\section{Discussion}

Communities have experienced social and economic loss, and their contribution towards conservation neglected. Results show that communities were involved prior to park expansion, but their opinion on how the process could be handled were not taken into account when decisions were made. Authorities already had pre-deter- 
mined decision to relocate communities, perhaps involving them was just a formality. The difference among community members with regards to their involvement before the eviction show the deep rooted social conflict embedded within the community. Majority of those who claimed to be involved wanted pastoralists to be removed in the area given the on-going internal conflict among different ethnic groups. Since most of the communities displaced were pastoralists, loss of Ihefu as a grazing land counted more than other losses.

The displaced communities were given cash to compensate their loss. In addition, evicted communities were given a plot to build new home. But since majority did not choose to stay in the allocated area, most complain that the compensation was not enough. It was not clear how the agreement was between Ikoga Mpya and TANAPA with regards to the new built facilities i.e. school, water well, and dispensary. Three years after eviction only the water well was functioning. Four classes were not used because there were no facilities. Similarly, the dispensary had no equipment, no health workers. Importantly, there were no bathrooms on both facilities.

Subsistence agriculture is the main economic activity for majority of rural communities hence depriving them access to agricultural land felt as a big loss. Some lost areas to conduct their petty business and others areas for livelihood activities such as fishing, charcoal burning and firewood collection. Access to, and ownership of resources is often associated with place attachment. Community pride identity are the outcome of people living in the area for several years, For Sangu communities, this too was lost. Gone too is the authority that Clan elders had on traditional and ritual places, one can conclude that, in years to come, those ritual practices that used to be carried out by the Sangu will be forgotten because the NG'iriama is now part of the national park and clan elders have no access to it. Generally, the cost of conservation incurred by the displaced communities is higher than the benefit received.

Although the expansion of Ruaha National Park is regarded as a success toward rescuing the Usangu wetlands and its surrounding areas, the idea neglect the fact that traditionally the Sangu had been managing the area for several decades. The expansion of Ruaha National Park is similar to what has happened elsewhere, in and outside Tanzania regardless of call for participatory approaches to conservation. The traditional rights over resource access, utilization and ownership around Ruaha National Park were shifted from rural communities to the state under TANAPA custodianship. The operation to evict pastoralists and relocate communities hence, changed the livelihood pattern for majority of rural communities.

The effects caused by displacement are distributed unequally among the local people, with the least powerful people experiencing most misfortunes. The inability of the rural communities to resist eviction or to claim for adequate compensation for their losses, display the power of the conservation approach in place (i.e. fortress conservation) and weakness of the rural resistance [39]. The fortress conservation assumed that, trade-offs existed between conservation and development [40], and that communities are homogenous with similar interest of saving wildlife forgetting that all these narratives cannot be treated similar. In Usangu area, local differences were clearly depicted (farmers vs. pastoralists; subsistence vs. commercial hunting) and reasons elaborated.

With the increase in human population and the need to include people in conservation planning, protected areas today cannot function in isolation from the human-modified ecosystem; hence, the need to embrace participatory approaches to achieve lost lasting conservation outcomes. Approaches that address the needs and knowledge of rural communities, together with institutional and legal framework that provide enabling environment for rural communities to be part of the conservation process are the key to conservation success.

\section{Conclusion}

This research did not include evicted pastoralists who moved to Lindi and Pwani Regions in its analysis. Similarly, the study did not quantity the level of impact that communities experienced during relocation and reestablishment process. Therefore, further research that will assess the livelihood of pastoralists residing at Lindi and Pwani Regions is important. Furthermore, research that focuses on analysing conservation displacement impact based on community composition and characteristics is important to understand the contribution of social scale in displacement impacts.

\section{References}

[1] United Nations Environment Programme (2002) UNEP in 2002: Environment for Development. UNEP, 63 p.

[2] Bertzky, B., Corrigan, C., Kemsey, J., Kenney, S., Ravilious, C., Besançon C. and Burgess, N. (2012) Protected Planet Report 2012: Tracking Progress towards Global Targets for Protected Areas. IUCN, Gland, Switzerland and UNEP- 
WCMC, Cambridge.

[3] Watson, J.E.M., Dudley, N., Segan, D.B. and Hockings, M. (2014) The Performance and Potential of Protected Areas. Nature, 515, 67-73. http://dx.doi.org/10.1038/nature13947

[4] Wells, M. and Brandon, K. (1992) People and Parks: Linking Protected Areas Management with Rural Communities. World Bank/World Wildlife Fund/US Agency for International Development, Washington DC.

[5] Schwartzman, S., Nepstad, D. and Moreira, A. (2000) Arguing Tropical Forest Conservation: People versus Parks. Conservation Biology, 14, 1370-1374. http://dx.doi.org/10.1046/j.1523-1739.2000.00227.x

[6] Cernea, M.M. and Schmidt-Soltau, K. (2006) Poverty Risks and National Parks: Policy Issues in Conservation and Resettlement. World Development, 34, 1808-1830. http://dx.doi.org/10.1016/j.worlddev.2006.02.008

[7] McElwee, P.D. (2010) Resource Use among Rural Agricultural Households near Protected Areas in Vietnam: The Social Costs of Conservation and Implications for Enforcement. Environmental Management, 45, 113-131. http://dx.doi.org/10.1007/s00267-009-9394-5

[8] Sirima, A. and Backman, K. (2013) Communities' Displacement from National Park and Tourism Development in the Usangu Plains, Tanzania. Current Issues in Tourism, 16, 719-735. http://dx.doi.org/10.1080/13683500.2013.785484

[9] Masozera, M., Erickson, J.D., Clifford, D., Coppolillo, P., Sadiki, H.G. and Mazet, J.K. (2013) Integrating the Management of Ruaha Landscape of Tanzania with Local Needs and Preferences. Environmental Management, 52, 15331546. http://dx.doi.org/10.1007/s00267-013-0175-9

[10] Brockington, D. and Igoe, J. (2006) Eviction for Conservation: A Global Overview. Conservation and Society, 4, 424471.

[11] Msoffe, F.U., Said, M.Y., Ogutu, J.O., Kifugo, S.C., De, J., Gardingen, P.V. and Reid, R.S. (2011) Spatial Correlates of Land-Use Changes in the Maasai-Steppe of Tanzania: Implications for Conservation and Environmental Planning. International Journal of Biodiversity and Conservation, 3, 280-290.

[12] Schama, S. (1996) Landscape and Memory. Fontana Press, London.

[13] Agrawal, A. and Redford, K.H. (2009) Conservation and Displacement: An Overview. Conservation and Society, 7, 110. http://dx.doi.org/10.4103/0972-4923.54790

[14] Walsh, M. (2008) Pastoralism and Policy Processes in Tanzania: Mbarali Case Study. TNRF, Arusha.

[15] Walsh, M. (2012) The Not-so-Great Ruaha and Hidden Histories of an Environmental Panic in Tanzania. Journal of Eastern African Studies, 6, 303-335. http://dx.doi.org/10.1080/17531055.2012.669575

[16] Hutton, J., Adams, W.M. and Murombedzi, J.C. (2005) Back to the Barriers? Changing Narratives in Biodiversity Conservation. Forum for Development Studies, 2, 341-370. http://dx.doi.org/10.1080/08039410.2005.9666319

[17] Cernea, M. and Schimdt-Soltau, K. (2006) Poverty Risks and National Parks: Policy Issues in Conservation and Resettlement. World Development, 34, 1808-1830. http://dx.doi.org/10.1016/j.worlddev.2006.02.008

[18] Adams, W.M. and Hulme, D. (2001) If Community Conservation Is the Answer in Africa, What Is the Question? Oryx, 35, 193-200. http://dx.doi.org/10.1017/S0030605300031847

[19] Phua, M. and Minowe, M. (2005) A GIS-Based Multi-Criteria Decision Making Approach Toforest Conservation Planning at a Landscape Scale: A Case Study in the Kinabalu Area, Sabah, Malaysia. Landscape and Urban Planning, 71, 207-222. http://dx.doi.org/10.1016/j.landurbplan.2004.03.004

[20] Brockington, D. (2002) Fortress Conservation: The Preservation of the Mkomazi Game Reserve, Tanzania. James Currey, Oxford.

[21] Mowforth, M. and Munt, I. (2007) Tourism and Sustainability: New Tourism in the Third World.

[22] Deihl, C. (1985) Wildlife and the Maasai. Cultural Survival Quartely, 9, 37-40.

[23] United Republic of Tanzania (URT) (1994) The Natioal Park Policy. Government Printer, Dar es Salaam.

[24] Baldus, R.D. and Siege, L. (2001) Experiences with Community Based Wildlife Conservation in Tanzania. Tanzania Wildlife Discussion Paper No. 29.

[25] Gregg, G. (2005) The Legal System and Wildlife Conservation: History and the Law’s Effect on Indeginous People and Community Conservation in Tanzania. http://www.law.georgetown.edu/

[26] Honey, M. (2008) Ecotourism and Sustainable Development. Island Press, London.

[27] Benjaminsen, T.A., Bryceson, I., Maganga, F.P. and Refseth, T. (2011) Conservation and Land Grabing in Tanzania. Paper Presented at the Global Land Grabbing, University of Sussex, Sussex.

[28] TTB (2008) Tanzania the Land of Kilimanjaro, Zanzibar and the Serengeti.

[29] TANAPA (2008) Ruaha National Park. www.tanzaniaparks.com 
[30] Arskey, H. and Knight, P. (1999) Interviewing in Social Scientist: An Introductory Resources with Examples. Sage Publication, London.

[31] Nelson, F., Gardner, B., Ignoe, J. and Williams, A. (2009) Community-Based Conservation and Maasai Livelihood in Tanzania. In: Homewood, K., Patti, K. and Pippa, T., Eds., Staying Maasai? Livelihood, Conservation and Development in East African Rangelands, Springer, New York, 299-334. http://dx.doi.org/10.1007/978-0-387-87492-0_8

[32] Walsh, M. (1996) Fish and Fishing in the Rivers and Wetlands of Usangu. East African Natural History Society Bulletin, 26, 42-47.

[33] Alexander, J.C., Giesen, B. and Mast, J.L. (2006) Social Perfomance: Symbolic Action, Cultural Pragamtics and Ritual. Cambridge University Press, Cambridge. http://dx.doi.org/10.1017/CBO9780511616839

[34] Kajembe, G.C., Mbwilo, A.J., Kidunda, R.S. and Nduwamungu, J. (2003) Resource Use Conflicts in Usangu Plains, Mbarali District, Tanzania. International Journal of Sustainable Development \& World Ecology, 10, 333-343. http://dx.doi.org/10.1080/13504500309470109

[35] Franks, T., Lankford, B. and Mdemu, M. (2004) Managing Water amongst Competing Uses: The Usangu Wetland in Tanzania. Irrigation and Drainage, 53, 277-286. http://dx.doi.org/10.1002/ird.123

[36] Charnley, S. (1997) Pastoralism and Property Rights: The Evolution of Communal Property on the Usangu Plains, Tanzania. African Economic History, 25, 97-119. http://dx.doi.org/10.2307/3601881

[37] Robbins, P. (2012) Political Ecology: A Critical Introduction. 2nd Edition, Blackwell, Oxford.

[38] Mbarali District Council (2009) Mbarali District Investment Profile.

[39] Brockington, D. (2004) Community Conservation, Inequality and Injustice: Myths of Power in Protected Area Management. Conservation and Society, 2, 411-432.

[40] Jones, S. (2006) A Political Ecology of Wildlife Conservation in Africa. Review of African Political Economy, 33, 483495. http://dx.doi.org/10.1080/03056240601000911 